\title{
The Market Model of Education and the Threat to Canadian Universities
}

\author{
Howard Woodhouse \\ University of Saskatchewan
}

\begin{abstract}
The market model of education, which is enveloping Canadian universities, endangers the advancement and dissemination of shared knowledge as a public good. By reducing all knowledge to a private good, it fails to acknowledge that education has opposing goals, motivations, methods, and standards of excellence to those of the corporate market. Statements made by leading advocates of the market model exhibit a habitual tendency to expunge all evidence that does not serve the overriding goal of maximizing private money profits. When taken together, these characteristics suggest that the market model of education has become a totalizing moment in human affairs, which Canadian faculty and students must oppose if the university as a public institution is to survive.
\end{abstract}

Key Words: market model in education, higher education, Canadian universities

\section{RESUMEN}

El modelo de mercado en educación que se está desarrollando en las universidades Canadienses pone el peligro el avance y la diseminación del conocimiento entendido como bien público para ser compartido. Al reducir toda forma de conocimiento a un bien privado, se deja de reconocer que la educación tiene objetivos, motivaciones, métodos, y niveles de excelencia que se oponen a aquéllos del mercado corporativo. Declaraciones hechas por los defensores del modelo de mercado exhiben una tendencia habitual a suprimir toda evidencia que no sirva el objetivo central ques es potenciar al máximo las ganancias privadas.El análisis de estas características sugiere que el modelo educacional de mercado se ha convertido en un momento totalizante en relación al desarrollo humano. Las Facultades de Educación deben oponerse a este modelo si es que desean que la universidad como institución pública sobreviva.

Descriptores: modelo de mercado de educación, educación superior, universidades canadienses

\section{RÉSUMÉ}

Le modèle de marché d'éducation, qui est en traîn d'envelopper les universités canadiennes, menace l'avance et la dissémination des connaissances partagées comme bien collectif. En réduisant toutes les connaissances à un bien privé, le modèle n'arrive pas à reconnaître que l'éducation a des buts, des motivations, des méthodes et des normes d'excellence qui s'opposent à ceux du marché des entreprises. Des déclarations faites par de principaux partisans du modèle de marché démontrent une tendance habituelle à supprimer toute preuve qui ne sert pas au but prépondérant de maximiser les profits monétaires privés. Quand ces caractéristiques se voient ensembles, cela suggère que le modèle de marché est devenu un moment totalisant dans les affaires humaines, ce à quoi la faculté et les étudiants canadiens doivent s'opposer si l'université comme institution publique doit survivre.

Mots-clefs: modèle de marché d'éducation, etudes supérieures, universités canadiennes 


\title{
Introduction
}

The learned and imaginative life is a way of living, and is not an article of commerce (Whitehead, 1929/1957, p. 97).

\begin{abstract}
A t the Summit of the Americas held in Quebec City in April 200I, Prime Minister Jean Chretien was asked about the dangers to public university education posed by the establishment of private, American, for-profit universities in Canada. He dismissed the question, suggesting that the journalist seek out the government of Alberta for an answer, since the Canadian Constitution declares university education a provincial matter. While formally correct, the head of state thereby tried to expunge any notion that the privatization of universities might be a matter of public concern. Ironically, the very meeting of the Free Trade Area of the Americas which Chretien was hosting was designed to draw up a wide range of market-based policies that would hasten the commercialization of universities throughout the hemisphere.

Only two months earlier, the DeVry Institute of Technology, a United States-based private corporation with twenty-one campuses across North America, had been granted the right to award academic degrees by the government of Alberta. Under the North American Free Trade Agreement (NAFTA), DeVry can now challenge government funding to postsecondary education insitutions, claiming that it gives public universities "a competitive advantage." Indeed, NAFTA requires the Alberta government to provide a "level playing field" for both public and private institutions, and opens up the post-secondary "market" to American and Mexican private corporations that meet the same conditions as DeVry (DeVry Given Degree-Granting Privileges, 200I, p.9).

Indeed, for almost two decades the Canadian federal government has actively sought the privatization of university education and research in a manner that belies Chretien's dismissal of the problem (Fisher \& Rubenson, I998; Tudiver, 1999b). In May 1999, for example, the Prime Minister's Advisory Council on Science and Technology received a report from the Expert Panel on the Commercialization of University Research calling for "innovation" to become the fourth mission of universities (the first three being teaching, research, and community service). The report defined innovation in purely commercial terms as "the process of bringing new goods and services to the market, or the result of that process" (Report of the Expert Panel, 1999). The goal of scientific research conducted at universities was now to enable private corporations based in Canada to maximize their money profits by bringing goods and services to a globally competitive market. This exclusively market-based goal, embraced so enthusiatically by the federal government, engendered opposition from university faculty, especially those in the sciences (Letter to Jean Chretien, 2000), as well as from their local and national associations (CAUT Commentary, 1999). Yet universities in Canada continue to transform themselves from institutions where knowledge is pursued as a public good to sites for producing knowledge that meets the market needs of business corporations (Polster, 1998, 2000; Tudiver, 1999a; Franklin, 2000).

The most comprehensive analysis of the market model of education has been articulated by John McMurtry, a philosopher at the University of Guelph. McMurtry
\end{abstract}


shows how the corporate market subordinates the distinctive functions of universities to its narrowly defined goal of making ever more money for corporate stockholders (I988, I99I, I998, 2000). By overriding the differences between the distinctive goals, motivations, methods, and standards of excellence of education, the market threatens universities' autonomy and their very ability to advance and disseminate knowledge for the public good (McMurtry, 1998, pp.I88-190). In this paper, I use his critical framework to analyze the statements of several advocates of the market model. I argue that in their refusal to acknowledge the opposition between education and the market they aim to liquidate the critical pursuit of knowledge taking place in universities. My analysis is consistent with the recommendation of two other Canadian colleagues, who wrote that:

This new market language needs to be deconstructed to unveil vested interests in reproposing notions of freedom and democracy. (Bruno-Jofre \& Hendley, 200o, p. 46)

Unless opponents of the market model show precisely how its very language distorts the meaning of the foundational concepts of knowledge, freedom, and democracy, we shall have failed in our task as critical intellectuals (McMurtry, 1988). This totalizing moment in human affairs endangers the distinctive functions of universities, threatening to replace education with "a new form of barbarism" that reduces knowledge to an instrument for private gain (McMurtry, 1998, p.192).

\section{Opposing Goals}

The goal of university education and research is to advance and disseminate knowledge by sharing it with others. The overriding goal of the corporate market, on the other hand, is to maximize private money profits. These "aims and process of education and the market are not only distinct, but contradictory" (McMurtry, I99I, p. 38). The contradiction is between education as a public process, whose goal is to share knowledge among those seeking it, and the market's goal of maximizing private profits in the form of money. Put differently, the goals of pursuing public knowledge and private money profits contradict one another, because the processes of sharing knowledge and accumulating private money profits are incompatible. This oppositional character is readily understood as follows:

The principles that benefit markets undermine the objectives of education and conversely, education that achieves its intended purposes cannot serve well as a marketable commodity. (Newson, 1992, p. 234)

More specifically, the goals of education and the goals of the market are based on "wholly distinct and often opposed logics of value" (McMurtry, I998, p. 25): one enables deeper and broader understanding of reality, while the other maximizes corporate stockholder value. Sharing knowledge with others is a valuable activity in the context 
of an institution that enables professors and students to engage freely, and without fear of censure, in a public process of sharing critical understanding. Rather than excluding others, the logic of this process is inclusive of their desire for knowledge, which "is maximized the more its accumulation is shared by others, and the more others have access to every step of its development" (McMurtry, I99I, p. 38). The goal of teaching, scholarship, and research is to increase the accumulation of knowledge by sharing it among all those who seek it.

Advocates of the market model make a fundamental error in identifying the goals of education with those of the market, where "private profit is acquired by a structure of acquisition that excludes others from its appropriation" (McMurtry, I99I, p. 38). The more that private money profits are accumulated by individuals or business corporations, the less that others have access to the use of such money or to gaining control over it. The logic of the market excludes all those who lack the money to pay from having access to its goods. In contrast, the inclusive logic of education enables all who seek knowledge to share in its accumulation.

This basic opposition between the two logics of value is not recognized by advocates of the market model, as I shall show. The initial report of the Corporate Higher Education Forum provides an early example of this refusal to acknowledge their opposing value systems. The Forum, an agglomeration of chief executive officers of Canadian-based multinational corporations and university presidents, commissioned two private-sector economists to assess the possibilities for increasing "cooperation" between universities and business in order to make the Canadian economy internationally competitive. Judith Maxwell and Stephanie Currie produced Partnership for Growth in 1984, anticipating many developments, like "business partnerships," "research parks," "targeted research," and "research consortia" that have since engulfed universities. Their goal was to determine how best to attune "the research effort and the university curriculum ... more closely to the needs of the marketplace." In doing so, the values or "cultural differences" distinctive of universities, quickly dissolve into those of the market (Maxwell \& Currie, I984, I-4). ${ }^{1}$ Maxwell and Currie see these "cultural differences" as a major stumbling block to greater "cooperation" between universities and business since they reflect "the different values, expectations, and mode of operation of the two types of institutions." This barrier must be overcome, and it is universities which should adapt to the corporate market, not vice-versa. Their commitment to "the extension and transmission of knowledge ... freedom of communication and publication ... [and] creative and self-paced ... selection and management of their research" are at odds with the "profitability" and "efficiency" in delivering products or services that determine value in the market. Here, "research is oriented towards the development and commercialization of new and improved products" and "deadlines ... and proprietary rights are closely guarded" so as "to obtain a competitive edge in the marketplace." Lest there be any uncertainty about which set of values should dominate the other, Maxwell and Currie write: 
The nature and scope of corporate-academic collaboration will be determined by the needs of the corporation and by the areas of expertise that a university can offer. (Maxwell \& Currie, 1984, p. 3. My italics.)

Since the needs of business corporations are driven by the market values of "profitability" and "efficiency," universities wishing to "collaborate" with them must conform to these same values. This means discarding their outmoded goal of advancing and disseminating shared knowledge in favour of the pursuit of private money profits. Indeed, this new goal will determine the "areas of expertise" in which they will provide private goods and services to "the corporation." In order to make this regime of externallydetermined, market-oriented research and teaching work smoothly, universities must discard academic freedom, whose "creative and self-paced" approach no longer has a place in the "new reality." Nothing less than the subordination of the process of disseminating shared knowledge to their own goal of maxmizing private money profits will satisfy business corporations. This hastens the reduction of universities' values to those of the market since, in the words of historian Michiel Horn, "one set of values trumps the other, and ... the corporations hold the high cards" (Horn, I999, p. 335).

Among influential individuals subscribing to the market model of education is Dr. Tom Brzustowski who, as Ontario's Deputy Minister of Colleges and Universities, made the following statement:

I contend that the one global object of education in Ontario must necessarily be a greater capability of the people of Ontario to create wealth ... [to] export products in which our knowledge and skills provide the value added ... to develop new services which we can offer in trade on the world market (I8).

Brzustowski not only advocates the creation of wealth as "the one global object of education," but apparently considers it to be the only conceivable goal of university education and research. The clause "must necessarily be ... to create wealth" implies there can be no other goal-as a matter of necessity. This market-based logic disregards the sharing of knowledge as having any part to play in the goal of university education. Indeed, "knowledge and skills" become instruments for creating "value added" to "products" and "new services" to be sold "on the world market," that is to say, mere conduits for reducing costs and increasing revenues for business corporations. There is no conceptual room here for the dissemination of shared knowledge as a distinguishing goal of universities. Rather, their goal is now to provide services (in the form of "value added products") so that business corporations can maximize their money profits. Brzustowski's refusal to acknowledge the fundamental differences between the goals of education and those of the market is a prime example of the kind of "reasoning" that leads to the subordination of the former to the latter. By dissolving the distinction between education and the market, he liquidates the idea that knowledge might have a value other than its market value or price (McMurtry, 1998, p. 190). This distorted view reduces universities to machines for generating private wealth by identifying their goals with those of the market. Ironically, Brzustowski does so as a public representa- 
tive of public education and a former Vice-President Academic of the University of Waterloo (McMurtry, 200o).

As President of the Natural Sciences and Engineering Research Council of Canada, Dr. Brzustowski continues to promote this same view of all education. His participation on the "Expert Panel on the Commercialization of University Research," to which I have already alluded, was guaranteed by his clear identification of the goals of universities with those of the market. As I have pointed out, this report for the Prime Minister's Advisory Council on Science and Technology called for exclusively market-based "innovation" to become the fourth mission of universities (Report of the Expert Panel, 1999). The report clearly reflected not only Brzustowski’s views, but those of the majority of the "expert panel" who were presidents or vice-presidents of banks and business corporations. Together they ensured that the overriding value of maximizing private money profits was formally recognized as a mission of universities (Tudiver, I999a).

The same kind of flawed reasoning pervades the "Employability Skills Profile" published by the Corporate Council on Education of the Conference Board of Canada, a powerful lobby group of some "twenty-three corporate members" engaged in marketbased educational reform in universities, colleges and schools. The profile articulates "the critical skills required of the Canadian workforce" to "ensure Canada is competitive and successful in the global economy," and has been widely circulated as a kind of corporate manifesto for marketizing all levels of education. Indeed, the goals of education are identified with those of the corporate market without any justification, while the skills enumerated are all designed to satisfy "Canadian employers [who] need a person who can get, keep and progress on a job and ... get the best results." The goal of "academic skills," in particular, is to "provide the basic foundation to get, keep and progress on a job and to get the best results" by "adding value" to a company's products. The "basic foundation" of academic work is thereby reduced to those skills that maximize private money profits. Students trained in this way are unlikely to gain an understanding different from, let alone critical of, the corporate world in which they will eventually work. The profile makes no mention of "understanding" at all, but regards all learning as a matter of acquiring skills in isolation from the academic disciplines in which they are used. The goal of learning to "think critically and act logically," for example, is "to evaluate situations, solve problems and make decisions" in ways useful to future employers (Conference Board of Canada, I992, pp. I-2). Problem-solving of this kind is a matter of acquiring skills in the sense of "discrete and repeatable exercises that can be improved by practice," not as part of a broader understanding rooted in the various disciplines of thought (Woodhouse, I991a, p. 33). This excludes the possibility of students developing any deeper understanding of physics, english literature, art history, or reality itself. Students trained in this way cannot pose critical questions of the knowledge claims made in such disciplines because they lack the understanding needed to do so. Their ability to engage in critical thought about social reality is limited in precisely the same way.

Indeed, "academic skills," decoupled from any disciplinary base, are really no different from "personal management skills," which enable "a person ... to get, keep 
and progress on a job and to get the best results." The only difference is that personal management skills achieve this goal by training individuals to adopt the correct "attitudes and behaviours" so as to "contribute to the organization's goals" of maximizing corporate stockholder value (Conference Board of Canada, I992, p. 2). The goal of university education is to train students to be loyal to this overriding value. Once again, no reasons are given for this. The Conference Board simply presuppose that the only goal of university education is to transmit skills that will enable future employees to provide "value-added" to the companies for which they work.

The Corporate Higher Education Forum, Brzustowski, and the Conference Board of Canada all ignore the fact that universities have quite different goals from the market. Knowledge acquisition is an activity in which those engaged in the search for critical understanding have access to the shared good of knowledge (Canadian Association of University Teachers, 1979, p. 46). By reducing education to the production of knowledge and skills that give "value-added" to the goods and services sold by business corporations, advocates of the market model liquidate the opposing values of education. They are blind to the fact that these two systems seek quite different goods: one aims at material possession of uniform artifacts, while the other strives for knowledge that enhances the distinctive mental capacities of those who seek it. The possession of material goods is limited by those who own them, since they can no longer be used by others. Mental or intellectual goods cannot be "owned" in this way because their possession actually enhances the understanding of others through teaching, scholarship and research (McMurtry, I99I; Russell, I916). The market model of education simply cannot accomodate this deep structural nature of education because its doctrine depends on the presupposition that the goal of all human activity is to maxmimize money profits for private stockholders. By systematically disregarding any counter-evidence, Brzustowski, in particular, tries to expunge any opposing position that values knowledge as a shared good. In this manner, the market model of education subordinates the pursuit of knowledge as a distinctive goal of universities to the market goal of maximizing private money profits.

\section{Opposing Motivations}

The determining motivation of education is to satisfy the desire for knowledge of anyone who seeks it, whether they have the money to pay or not. Knowledge as a shared good is accessible to everyone who desires it, provided they fulfill its requirements for themselves. In contrast, the determining motivation of the market is to satisfy the wants of anyone who has the money to purchase what is wanted. All those who sell goods in the market proclaim its ability to "satisfy the wants of customers" as a universal criterion of its efficiency (McMurtry, I99I, pp. 38-9; I998, p. I89). When the same motivation is applied to education, however, it wreaks havoc with the distinctive activities of university teaching and learning.

William A. Cochrane, former President and Chief Executive Officer of Connaught Laboratories Limited in Toronto, provides a good example of why the determining motivation of the market cannot apply to education. In suggesting that universities 
must satisfy the wants of their "customers," who comprise "the general public, the business or industrial sector and government," Cochrane fails to recognize the opposing logics of value at work in these very different spheres of human activity. He regards the determining motivation of the market to satisfy the wants of customers, as a fundamental principle that "should be at the forefront of any activity of universities or institutions of higher learning." The principle is a simple one: "stay near the customer," and he believes it would enable universities, like buyers and sellers in the market, to "determine the customer's short- and long-term wants" (Cochrane, I986, pp. 29-30). This principle presupposes that want-satisfaction should be the overriding motivation for universities just as it is for the market. Yet no evidence is offered in support of this claim. Rather, Cochrane begs the question by assuming that the dominant motivation of university education is to satisfy the wants of those who have the money to buy it. If, however, universities were to "stay near the customer," they would ignore the fact that the distinctive goods of knowledge and understanding are to be shared with all those who seek them.

Cochrane's position is at odds with an entire tradition based on the opposing motivation of satisfying the desire for knowledge of anyone who seeks it as far as s/he is willing to pursue it. Satisfying the wants of "the customer" in purely market terms is not only different from, but actually opposed to, the development of the kind of understanding which typifies university education. Wanting to buy or consume the latest product often blocks students from gaining an understanding of their subject matter, because it diverts their attention away from the self-discipline required for intellectual growth towards a fascination with "commercial television, rock records or mall wandering" (McMurtry, I99I, p. 39). The danger here is that by satisfying customers' wants the market may well sap their ability to develop a comprehensive understanding of the disciplines they study, or of reality itself. ${ }^{2}$ Where want-satisfaction as the basic motivation of market activity becomes a fundamental principle of education, in the manner suggested by Cochrane, universities are in danger of becoming mere "shopping malls of the mind." Rather than enhancing intellectual growth, they try to satisfy those wants of "the customer" which stimulate further market activity, regardless of any understanding which students may develop.

Where this happens, the basic motivation of education is violated in at least two ways - the first with regard to the manner in which it is fulfilled. Here the overriding motivation of the market regards students' desire for knowledge as having no real import in the process of learning, replacing it with the satisfaction of their wants as "customers." Second, the beneficiaries of this process of fulfillment are quite different in the market model where only those who have the money to pay for such services can benefit from a university education. When the determining motivation of the market, which requires "customers" to pay for the "private goods" they buy, is applied to universities significant increases in tuition fees are one obvious way of putting the principle into practice. Indeed, as university education is regarded as a private rather than a shared public good, and government financing shrinks accordingly, Canadian students now pay over $64 \%$ more in tuition fees than a decade ago (Students Pay More for Less, 200I). 
In Britain, where tuition fees have risen even more dramatically during the past twenty years, some universities welcome this development as a market opportunity. Sir Geoffrey Holland, Vice-Chancellor of the University of Exeter, recently established a "complaints procedure" for better serving the wants of "customers" attending his institution:

This is very much in the spirit of the age as tuition fees have clearly completed the process of making students our "customers," "paying guests" as we should think of them (Holland, 1999).

True to the overriding motivation of the market, Holland regards those "customers" who can afford to pay for the market goods of education as worthy of a "complaints procedure" that satisfies their wants. He considers this procedure as an embodiment of "the spirit of the age," as though it reveals some deeper purpose at work in the commercialization of his campus. ${ }^{3}$ Acknowledging that high "tuition fees have clearly completed" the "process of making our students our customers," he suggests they now be regarded as "paying guests," presumably because they can also pay for private accomodation in or around the university. Their status has risen as a direct result of the increase in their market activity and, as their wants for private goods grow, the university responds by establishing a mechanism that ensures their satisfaction in the market. Nowhere does Holland allow that the desire for knowledge, regardless of students' ability to pay, should be a criterion for determining access to the "complaints procedure." More importantly, he rules out in principle the possibility of establishing an evaluation process for determining the quality of teaching on the basis of what students have actually learned, and how well their capacity for critical thought has grown. This would require him to recognize that the desire for knowledge and its satisfaction in the growing capacity for independent thought are the basis for teaching and learning, not some externally imposed requirement like the ability to pay. In "the spirit of the age," Holland hastens the market domination of universities by disregarding their distinctive motivation in favour of a mechanism that furthers the want-satisfaction of his "paying guests."

The flawed approach advocated by Cochrane and Holland is silent about the need for universities to satisfy students' desire for knowledge regardless of their ability to pay, because it focuses narrowly on their wants for private goods in the market for which they must pay. Failure to recognize the opposing logics of the values embedded in these two activities is the result of their adherence to the presuppositions of the market model. Their refusal to consider whether universities might conceivably give rise to a motivation different from that of the market is reminiscent of the way in which Brzustowski, the Corporate Higher Education Forum, and the Conference Board expunged any counter-evidence to their views of the goal of universities. In both cases, reasoned argument is replaced by faith in the market's "invisible hand" as a mechanism capable of liquidating any remaining differences setting universities apart from the "new reality" in which the only conceivable motivation and goal are to make ever more money for private stockholders. 


\section{Opposing Methods}

The method of the market is to buy or sell ready-made products at whatever price one can get. This means that everything in the market is obtained by the money paid for it. By way of contrast, the method of education is never to buy or sell its goods to anyone, but to require of all those who would have it that they fulfill its requirements autonomously. As a result, "nothing that is learned in education is gotten by the money paid for it," for knowledge can only be earned through learning to exercise one's mental capacities for oneself. This is not a requirement in the market whose goods need not be earned autonomously or on the basis of one's own work. Ironically, the market's capacity to provide ready-made products and services to those who can pay for them often deprives consumers of the ability to think and act for themselves. This is most evident among the very rich who, dependent on others for everything they want, continue to demand the products they supply. The overwhelming desire to satiate their wants results in a kind of "infantile stage" in which any "responsibility for the production, preparation, delivery, and service of any of it" is absent.

An education that can be bought on the market, however, is "a fraud," while purchasing someone else's performance to replace one's own work is, in McMurtry's words, "an expulsionable cheat," precisely because the method of achievement in education "rules out the method of the market as its most essential violation." Attempts to buy and sell education as a ready-made product for whatever price one can get are opposed to the autonomous intellectual activity comprising the method of education. Furthermore, ready-made goods produced for the market depreciate in value as they are used, eventually wearing out. In contrast, the goods created by education are quite different, for "the more and longer an education is put to work, the better and more durable it grows" (McMurtry, I99I, pp. 39-40). As students' capacity for independent thought develops, they learn to use knowledge in different ways that enhance the scope of their understanding. Despite all this, advocates of the market model ignore the opposing logic of value, confusing the method of education with that of the market.

Dr. Michael R. Bloom, Senior Research Associate for the National Business and Education Centre of the Conference Board of Canada, is prominent among those who identify the method of education with that of the market. Not surprisingly, his views mimic those of the Conference Board's "Employability Skills Profile," but his own emphasis is on the competition that allegedly unifies education and the market:

The real issue is that our education system is competing with the education systems of other countries just as Canadian businesses are competing with their international rivals (Bloom, I996, p. I20).

The source of this alleged identification, then, lies in the fact that Canadian education and business "are [both] competing with their international rivals." Nor is this meant as a mere analogy since "our education system" is competing with other systems in just the same way as ("just as") Canadian businesses in the global market. Competition between Canadian universities and their "international rivals" is, allegedly, no different from the competition of the corporate market or, to put it more precisely, the two 
are identical. A claim of identity such as this can be represented as " $\mathrm{P}$ is the same as Q" which, in this case, becomes: "competition in education is the same as competition in the market." This can be further simplified by striking the terms "competition in" from either side of "is the same as," giving the following: "education is the same as the market." In trying to justify this claim, Bloom draws exclusively on evidence from the market, expunging all evidence or reason that might oppose his goal of reducing education to a market activity; notably, the distinctive method of university education requiring all those engaged in the search for knowledge to meet its requirements for themselves, not to receive it "problem free" as customers or clients. Competition defines both Canadian universities and the corporate market for Bloom, and the following prescription is designed to subordinate them to this "new reality."

"The real concern of business," he claims, is to help restore "our relative educational advantage" that "is slipping" in comparison with "the education systems of other countries ... with [whose] businesses ... we are competing in world markets" (Bloom, I996, p. I20). Upon closer examination, this "relative educational advantage" amounts to universities' ability to provide "comparative advantage" to Canadian-based business corporations. Improving their "relative educational advantage" requires universities to reduce the costs of business, increase corporate revenues, and enhance the competitiveness of business corporations by "adding value" to the products and services they provide. This ensures that the market principle of comparative advantage holds, whereby societies "produce those goods and services in which they have lower resource input cost than other countries." In this way, Canada's continuing specialization in such products as forestry, oil and gas, wheat, genetically modified canola, computer software and executive jets is secured by keeping their input costs down. The function of universities is to facilitate this process, so that "producers and sellers in the market are impelled to invest" in these Canadian products whose "costs are relatively low" (McMurtry, I998, p. I46).

Bloom systematically ignores education's own distinctive method by focusing exclusively on how universities can best contribute to the buying and selling of those ready-made products that reduce costs and maximize money profits for Canadianbased business corporations. What, one wonders, are the likely benefits to universities of this increase in market-based competition? Will universities be required to perform an exclusively service function to business by competing more effectively with their "international rivals" in order to receive government funding? Is Bloom prescribing greater dependency on the market for universities, or promoting the autonomous intellectual activity that their distinctive method requires? His failure to acknowledge the value of this method suggests strongly that he wishes to promote the dependency of universities on the market. Since both institutions allegedly share an identical method of competing with others in the buying and selling of ready-made products for whatever price they can get, there is no question in Bloom's mind that universities must serve the market. Yet, his whole argument rests on this very presupposition - that competition as the method of the market is identical to that of education. How well does this claim hold up in light of the counter-evidence which he dismisses? 
The brute fact is that Canadian universities are already competing internationally in just this way. They successfully manage to reduce the price of products and services, affording comparative advantage to business corporations in the market. Dr. Marc Renaud, President of the Social Sciences and Humanities Research Council of Canada, is among those who acknowledge this trend:

In reality, universities are now active in the market square, making alliances (socalled partnerships) and deals, exchanging goods and services in exchange for monetary and symbolic rewards, commercializing research results, scouting and selling talents, providing policy and organizational advice for government and industry, and so on (Renaud, I999, p. 5).

Not only are universities making the very "partnerships" with business favoured by Bloom and the Conference Board, they are "commercializing" their "research results," making "goods and services" available to companies in return for "monetary" and "symbolic rewards" (presumably, the opportunity to work with particular business corporations), and advising government and industry on both policy and strategy for use in world markets. Bloom obliterates such evidence in order to assert that the "relative educational advantage" of "our education system" is "slipping." The reason for this is simple: he wants universities to provide even more "value-added" goods and services to Canadian business corporations so as to provide them with an even greater comparative advantage.

In contrast, Renaud recognizes that the "commercialization" of universities threatens the critical search for knowledge, which has been their main function. This process can only take place where freedom of a distinctively educational kind flourishes, namely "freedom to disagree, freedom to challenge taken-for-granted assumptions, freedom to create from scratch" (Renaud, I999, p. I0). Among advocates of the market model, Renaud is unusual in his recognition of the value of academic freedom, and the manner in which it is opposed to the method of buying and selling products at whatever price one can get in the market. ${ }^{4}$ Posing critical questions of the presuppositions in any discipline, on the basis of evidence and reasoned argument, is an important activity in which universities must continue to engage, even though it may not result in any "value-added" products.

There is, however, a second kind of competition that Canadian universities currently engage in that neither Bloom nor Renaud recognize. This distinctive kind of educational competition creates value independent of any "comparative advantage" in the market. Universities consistently offer excellence in their programs and facilities, in the quality of teaching and scholarship they make available to students, and in the research they conduct in a wide variety of disciplines, all of which contributes to the public good. They compete with each other for a relative advantage in all these areas both in Canada and, increasingly, abroad. To take but one example, when faculty publish articles in refereed journals, as is a requirement of their employment, they are competing successfully with other faculty from around the world striving to do the same. Their work is reviewed by peers and judged to be of sufficient quality to merit 
publication in an international "marketplace of ideas" in which theories, evidence, arguments, and critical questioning of all knowledge claims are the goods exchanged. Such international competition at the core of university life goes largely unrecognized, because it is opposed to the method of the market where buying and selling readymade products for whatever price one can get is the regulatory norm. The method of education nurtures growth and the autonomous use of one's mental capacities which, in the case of publication, broadens and deepens the understanding of an international readership. This process cannot be considered identical to the opposing method of the market without undermining the educational vocation of universities irreparably.

\section{Opposing Standards of Excellence}

Competition among universities, then, secures a distinctive kind of educational excellence that is opposed to the market. Teaching, scholarship and research that broaden the understanding of students, researchers and international scholars meet the distinctive standards of educational excellence. They do so by ruling out any "one-sided presentation" of relevant evidence or using "manipulative conditioning" that impels their audience to agree with their findings. Any university program that did this would be deficient, because its knowledge claims would be partial and biased. Yet, the very devices deplored by educators are embraced by market agents to sell their ready-made products. "One-sided sales pitches" impelling customers to buy their products through the use of "operant conditioning" are common, since one measure of excellence in the market is how well a product is made to sell. Successful advertising campaigns do not generally make "rigorous demands on people's reason," preferring to utilize want-satisfaction on an unconscious level to increase the demand for private goods. University programs that achieve excellence, however, do so by ruling out "biased appeals to unconscious desires" for the very reason that they stunt the development of an inclusive understanding among students and faculty (McMurtry, I99I, p. 40). ${ }^{5}$

A second standard of excellence makes clear just how different the logic of value for education is from that of the corporate market. The "best product on the market" is one which is, and remains, "problem free for its buyer"-delivered "ready-made" for "instant easy use" with a "guaranteed replacement" if it does not work, and "repaired cost-free" whenever it needs maintenance. The opposite holds true of the best kind of education: it cannot be "produced or delivered by another" since this would negate the autonomous process of growth required to develop one's intellectual capacities. For the same reason, education can never be "ready-made nor instant," nor a "guaranteed replacement" provided "cost-free" if it does not work. The better the education, the harder students need to work, especially when overcoming any "failures" on the road to knowledge. For knowledge is very far from being "immediate in [its] yield," and an education worthy of the name can never be "problem-free," because it "poses ever deeper and wider problems the higher the level of excellence it achieves" (McMurtry, I991, p. 40; I998, p. I89). ${ }^{6}$

These opposing criteria of evaluation are not recognized by William A. Cochrane who, as former President and Chief Executive Officer of Connaught Laboratories, 
reduced the overriding motivation of education to that of the market, and now does the same with its standards of excellence. Impatient with the "natural inertia of universities" that "makes them too insular and ... not interested in the needs of business," he wishes them to do what "business wants" by increasing "their responsiveness to issues identified by business as important" (Cochrane, I996, pp. 35-42). To demonstrate their "responsiveness" to business, universities must employ different standards of evaluation drawn exclusively from the market to cover all their activities, including research. These market-based standards will rule out any "costly research that is unrelated to practical problems," replacing it with "sound basic research," having "specific objectives, responsible time frames, and adequate evaluation," all determined by business. Most important of all, the results of "basic research" will increase "the transfer of discoveries into industrial reality." For even "basic research" is to be evaluated in terms of the amount of "technology transfer" it provides to business corporations in the market. Excellence in both research and scholarship is no longer a matter of posing problems that broaden and deepen our understanding of reality-an approach quite "unrelated to practical problems" of concern to business. Rather, "adequate evaluation" is to be based on one criterion alone: how well any research enables "the transfer of discoveries into industrial reality" in order that business corporations maximize their private money profits (Cochrane, I996, pp. 34-5). ${ }^{7}$

Cochrane expunges the standards of excellence that are distinctive of education-impartial understanding and the ability to pose ever deeper problems of reality-in one fell swoop. He replaces them with criteria, which regard excellence as a matter of how well a product sells (in this case, how well research enables business to sell their products) and how problem-free such research is; namely, how easily it can be transferred into products for "industrial reality." These market-imposed standards of excellence mean that only research transferable into ready-made products for business corporations has any "value." Research that poses questions of reality so as to broaden and deepen our understanding is a remnant of universities' past, which they should "decide to discontinue" along with other "inadequate products or programs" that fail to meet the standards imposed by "industrial reality." Canadian universities must raise an "aggressive, constructive and unified voice" that is in tune with what "business wants," if they wish to survive in this "new reality" where servicing ready-made products for the market is the only standard of excellence (Cochrane, I996, pp. 30-43). ${ }^{8}$

\section{Opposing Realities}

A stark choice currently faces universities in Canada. They can become institutions whose goal is to provide services for business corporations, or they can resist this trend by asserting their remaining autonomy, and determine for themselves which goals, motivations, methods and standards of excellence they should embody. Typically, their distinctive logic of value has enabled universities to educate individuals, pursue scholarship, conduct research, and govern themselves in relatively autonomous ways. At their core, universities enable those in search of knowledge to develop their intel- 
lectual capacities for their own use. This constitutes both their goal and their standard of excellence. The better the education they offer, the more those who acquire it learn to think and act independently. This can only happen where the freedom to pursue knowledge critically is sustained by an institutional autonomy guaranteeing universities independence from powerful social forces, including governments and the market (Winchester, 1983, p. 48).

The corporate market is arguably the most powerful of these forces. Its influence already permeates universities in multiple ways: through the actions of chief executive officers like Cochrane, through organizations such as the Corporate Higher Education Forum and the Conference Board of Canada, through government officials like Brzustowski, economists like Maxwell, Currie, and Bloom, senior university administrators like Holland, and faculty wedded to the market model of education. The logic of value peculiar to the market is only successful where buyers are dependent on the readymade goods it produces. From the "brand-identification" reinforced by advertising, to the one-sided sales pitches extolling the "quality" of any product, to the internet's abundance of corporate "messages," the market's logic of value is achieved only where customers are dependent on the goods and services it offers, and the ways of thinking and acting it generates. Such a logic transforms universities and the pursuit of knowledge into "engines of economic growth," producing ready-made products and standardized ideas that only benefit the corporate market (Hinde, 1998).?

Throughout this article, I have shown how these same advocates of the market model of education tend to expunge all counter-evidence that does not accord with the overriding need to limit the scope of universities to "what business wants." This style of "argument" rules out opposition by liquidating the opposing logic of value, thereby justifying the total subordination of universities to the market. Only Marc Renaud, among those whom I have considered, acknowledges the importance of academic freedom to the process of critical understanding which sets universities apart from the market. The rest see such freedom as an encumbrance to the "increased efficiency" demanded by "industrial reality," and as one of many "inadequate products" to be eliminated from "aggressive" universities (Cochrane, 1986, pp. 30-43). They regard the corporate market as an all-encompassing or totalizing moment in human affairs, a "regime of truth" to which universities must be subservient lest its global rule be disturbed (Foucault, 199I). Faculty and students who oppose this market-based regime must reassert their "shared commitment to the university as an institution that should should exist to serve the public good rather than to produce privately owned goods" lest it disappear altogether (Newson, 1998, p. xii). 


\section{Notes}

I. For critical commentaries on Partnership for Growth, see Horn (1999); Newson and Buchbinder (1985 and 1988); and Woodhouse (1988).

2. Barrett (I99I) points out that the market provides goods that are not "consumed in passive or stultifying ways," like "tools, paint-brushes, hiking boots," which offer "endless possibilities of interest and challenge" (p.46) Yet, he begs the following question: can the distinctive goods of education be produced in the same way by means of market principles (Woodhouse, 199Ib)? For more on this question, see Woodhouse (2000).

3. For his views on the marketization of university teaching and research, see Holland (1994 For confirmation that high tuition fees in British universities exclude those "customers" unable to pay, see Utley (1999).

4. Like Bloom, however, Renaud (I999) believes that "as nations increasingly compete on a world-wide scale, so too must universities" in order to give business a comparative advantage in the corporate market (p. I2.)

5. Winchester also emphasizes impartiality and disinterestedness as important characteristics of knowledge (1983 Pp. 4I-59) as does Hare (1985), who shows that these characteristics do not preclude commitment to action on the part of faculty.

6. Some philosophers find this condition "that all educators should force challenges on their charges ... excessive" (Jarvie and Agassi, I990, p. 28) Such criticism is at odds with the University of Guelph Learning Objectives, which states that: "at the lowest level students are shown the possibilities of independent thinking by an instructor who ... challenges orthodoxies and criticizes received opinions" in Nash (1989, p. I0) It also contradicts the meaning of education itself (McMurtry, 1988, 2000).

7. Polanyi (1995), Nobel Prize Winner for Chemistry in 1986, objects to business and government placing such pressures on science, because they fail to recognize that "what, to the onlooker, appear to be worthless ends" actually embody the "creative effort" of discovery that embodies "a sense of direction sustained in the face of setbacks over a period of years" (p. 8)

8. This same theme is taken up by Thorsell, former editor-in-chief of the Toronto Globe and Mail, who declares that "universities are moving into an entrepreneurial culture in which ... excellence can be promised in a world of market accountability" (1998). Thorsell trades on the ambiguity of the term "excellence," hoping that his readership will identify with it, even though its implementation may mean the end of impartial, disinterested, and critical thought. As Horn (1999) points out, Thorsell's use of such persuasive techniques "belongs in the Newspeak world of marketing, and that is what the market requires" (p. 349).

9. The phrase "engines of economic growth" was used by Peter Mandelson, Britain's former Secretary of State for Trade and Industry, to describe the function of universities (Hinde, 1998).

\section{References}

Barrett, R. (I99I). Comment on "education and the market model." Paideusis, 5(I), 45-49. Bloom. M.R. (1996). Corporate involvement in the curriculum: Partnership not coercion. In Wideen W. \& M.C. Courtland (Eds..), The struggle for curriculum: Education, the state, and the corporate sector (pp. II9-I24). Burnaby, B.C.: Simon Fraser University, Institute for Teacher Education.

Bruno-Jofre, R. \& R. Hendley (2000). Public schooling in English Canada: Addressing difference in the context of globalization. Canadian Ethnic Studies, 32 (I), 38-53.

Canadian Association of University Teachers (1979). Model clause on academic freedom. Handbook of policy statements, guidelines and model clauses (p. 46). Ottawa.

CAUT commentary on the final report of the expert panel on the commercialization of university research (1999, September 30). Ottawa. 
Cochrane, W.A. (1986). Society's expectations: Staying near the customer. In Neilson, W.A.W. \& C. Gaffield (Eds.). Universities in crisis: A mediaeval institution in the twenty-first century (pp. 28-46). Montreal: The Institute for Public Policy.

Conference Board of Canada, corporate council on education (1992 March 24). Employability Skills Profile (Draft) (pp. I-2). Toronto.

DeVry Given Degree-Granting Privileges (200I March). Canadian Association of University Teachers Bulletin (pp. I-9).

Fisher, D. \& K. Rubenson (1998). The changing political economy: The private and public lives of Canadian universities. In J. Currie \& J. Newson (Eds.). Universities and globalization (pp. 77-98). Thousand Oaks, California: Sage Publications.

Foucault, M. (199I). Governmentality. In G. Burchell, C. Gordon, and P. Miller (Eds.). The Foucault Effect: Studies in Governmentality (pp. 87-IO4). London: Harvester Wheatsheaf.

Franklin, U. (2000). What is at stake? Universities in context. In Turk, J.L. (Ed.). The corporate campus: Commercialization and the dangers to Canada's colleges and universities (pp. 17-22). Toronto: James Lorimer.

Graham, W. (1989 and 1990). From the President. Ontario Confederation of Faculty Associations Bulletin, 6 (15) \& $6(22)$.

Hare, W. (1985). In defence of open-mindedness. Montreal and Kingston: McGill-Queen's University Press.

Hinde, J. (1998, December I8). Science packed off to market. The Times Higher Education Supplement (p. I).

Holland, G. (1994, November 4). Under-exploited assets. The Times Higher Education Supplement (p. vi).

Holland, G. (1999, Spring). Alma matters. Expression (p. 3).

Horn, M. (1999). Academic freedom in Canada: A history. Toronto: University of Toronto Press.

Jarvie, I.C. \& Agassi, J. (1990, December). Education: economic enterprise or intellectual challenge. Canadian Association of University Teachers Bulletin (p. 28).

Letter to the Right Hon. Jean Chretien (2000, March 8). [Signed by researchers and scientists across Canada].

Maxwell, J. \& Currie, S. (1984). Partnership for growth: Corporate-university cooperation in Canada. Montreal: The Corporate Higher Education Forum.

McMurtry, J. (1988). The history of inquiry and social reproduction: Educating for critical thought. Interchange, Ig (I), 3I-45.

McMurtry, J. (199I). Education and the market model. Paideusis, 5 (I), 36-44.

McMurtry, J. (1998). Unequal freedoms: The global market as an ethical system. Toronto: Garamond Press.

McMurtry, J. (2000, March). Seeing through the corporate agenda: Education, life-value and the global economy. Queen's University Faculty of Education Colloquium, Life and School: Education, Values and the Global Economy, Keynote Address.

Newson, J. (1992). The decline of faculty influence: Confronting the effects of the corporate agenda. In W. Carroll, L. Christiansen-Rufman, R. Currie \& D. Harrison (Eds.). Fragile truths: 25 years of sociology and anthropology in Canada (pp. 227-246). Ottawa: Carleton University Press.

Newson, J. (1998). Preface. In J. Currie \& J. Newson (Eds.). Universities and globalization: Critical perspectives (pp. xi-xii). Thousand Oaks, California: Sage Publications.

Newson, J. \& Buchbinder, H. (1985, February). Corporation, cooperation, cooptation. Canadian Association of University Teachers Bulletin (p. 32).

Newson, J. \& Buchbinder, H. (1988). The university means business: Universities, corporations and academic work. Toronto: Garamond Press.

Polanyi, J. (I995). Understanding discovery. In Moskovits, M. (Ed.). Science and society: The John C. Polanyi Nobel Laureate Lectures (pp. 3-1o). Toronto: Anansi Press.

Polster, C. (1998). From public resource to industry's instrument: Reshaping the production of knowledge in Canada's universities. Canadian Journal of Communication, 23 (I), 9I-Io6. 
Polster, C. (2000). The future of the liberal university in the era of the global knowledge grab. Higher Education, 39 (I), 19-4I.

Renaud, M. (1999). The universities of the future: From the ivory tower to the market square. Saskatoon: University of Saskatchewan Press.

Report of the expert panel on the commercialization of university research. (1999) [Presented to the Prime Minister's Advisory Council on Science and Technology]. Public Investments in university research: Reaping the benefits. Ottawa.

Russell, B. (1916). Principles of social reconstruction. London: George Allen and Unwin.

Students pay more for less (200I, June). Canadian Association of University Teachers Bulletin (p. I).

Thorsell, W. (1998, April 25). How to encourage universities to play to their strengths. The Globe and Mail.

Tudiver, N. (I999a, June). Growing commercial pressures endanger academic freedom. Canadian Association of University Teachers Bulletin (p. 4).

Tudiver, N. (1999b). Universities for sale: Resisting corporate control over Canadian higher education. Toronto: James Lorimer.

University of Guelph learning objectives (1989). In C. Nash (Ed.). Collaborative curriculum planning at universities: The proceedings of an invitational conference, June 9 (pp. 6-II). Guelph: University of Guelph.

Utley, A. (I999, May 28). I can only afford half the tuition fees. The Times Higher Education Supplement, p. 60.

Whitehead, A. N. (1929/1957). The aims of education and other essays. New York: The Free Press.

Winchester, I. (1983). Government power and university principles: an analysis of the battle for academic freedom in Alberta. In I. Winchester (Ed.). The independence of the university and the funding of the state: Essays on academic freedom in Canada. Toronto: OISE Press.

Woodhouse, H. (1988). Legitimation or transformation: The role of the state in university education. In C. Watson (Ed.). Readings in Canadian higher education. Toronto: OISE Press.

Woodhouse, H. (I991a). Review article: Robin Barrow, understanding skills, thinking, feeling, and caring. Paideusis, 4 (2), 33-8.

Woodhouse, H. (I991b). Contradicting the Market. Paideusis, 5 (I), 50-2.

Woodhouse, H. (2000). The seduction of the market: Whitehead, Hutchins, and the Harvard Business School. Interchange, 3I (2-3), I35-157. 